\title{
Aplikasi Pengeluaran Kas Belanja Bulanan Pada Administrasi Sekretariat Daerah Kabupaten Kubu Raya Berbasis Website
}

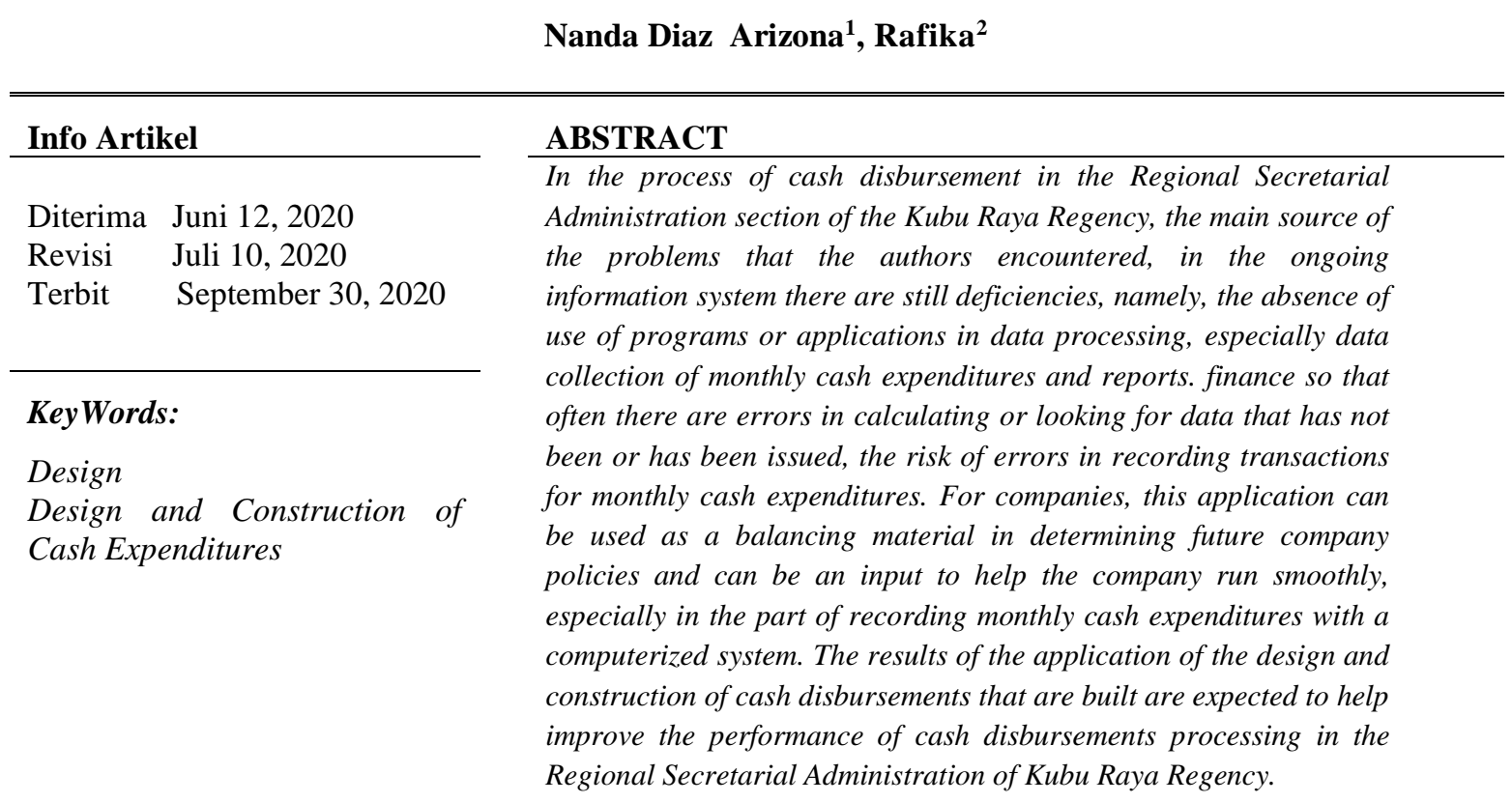

\section{Identitas Penulis:}

Nanda Diaz Arizona ${ }^{1}$, Rafika ${ }^{2}$, Universitas Bina Sarana Informatika Program Studi Sistem Informasi Akuntansi Kampus Pontianak Jalan Abdurrahman Saleh No.18 A Pontianak

Email: nanda.ndz@bsi.ac.id ${ }^{1}$, rafika.rfka@bsi.ac.id ${ }^{2}$

\section{PENDAHULUAN}

Kemajuan teknologi informasi adalah sesuatu yang tidak dapat dihindari dalam kehidupan ini, karena kemajuan teknologi akan sejalan dengan perkembangan ilmu pengetahuan. Teknologi informasi adalah istilah umum yang menjelaskan bahwa teknologi yang membantu kita dalam membuat, mengubah, menyimpan, mengomunikasikan dan/atau memberikn informasi. Teknologi informasi (Information Technologi) bisa disingat IT, IT atau Infotech. Kemajuan IT telah mengubah cara perusahaan dalam mengumpulkan data, memproses, dan melaporkan informasi keuangan [5].

Sistem merupakan bagian yang terpenting dalam kehidupan tak terkecuali dalam institusi pemerintah maupun swasta, karena untuk mengarahkan dan mengontrol semua bagian yang terdapat dalam institusi tersebut. Suatu system dikatakan baik apabila sistem tersebut memadai dan pelaksanaannya tidak menyimpang. Pelaksanaan sistem yang menyimpang terus menurus akan mengacaukan kegiatan operasional dan menghilangkan fungsi system itu sendiri. Setiap institusi selalu menjalankan aktivitas yang beragam. Untuk dapat menjalankan aktivitas tersebut khusunya yang berkaitan dengan kegiatan akuntansi, institusi tersebut membutuhkan suatu sistem akuntansi. Salah satu aktivitas yang sering dilakukan adalah aktivitas yang berhubungan dengan pengeluaran kas [1].

Setiap Instansi pemerintah maupun swasta sangat membutuhkan system informasi yang dapat mendukung suatu pekerjaan, memberikan informasi yang cepat dan akurat dalam menangani suatu pekerjaan, terutama di kedudukan sebagai dinas daerah. Sekretariatan merupakan unsur teknis dibidang membantu Kepala Badan dalam menyusun rencana kerja, penyusunan, pelaporan dan administrasi keuangan, 
penyelenggaraan, ketatausahaan dan administrasi kepegawaian, organisasi dan tatalaksana, hukum, hubungan, masyrakat, perlengkapan dan administrasi umum [3].

Sistem pencatatan perencanan Belanja Bulanan yang digunakan oleh kantor Sekretariatan Daerah Kabupaten Kubu Raya masih manual yaitu masih mencacat menggunakan Word dan Excel dalam proses pencatatan belanja bulanan yang digunakan hanya data-data laporan pengeluaran kas bulanan. Sehingga sering terjadinya kesalahan dalam pencatatan dan pembukuan, Tidak adanya tempat untuk menyimpan bukti transaksi laporan pengeluaran kas yang menyebabkan seringnya kehilangan bukti laporan transaksi tersebut.

\section{METODE}

\subsection{Metode Pengumpulan Data}

Proses pengumpulan data dilakukan oleh penulis agar memudahkan dalam mengetahui fakta, metode yang penulis lakukan dalam upaya pengumpulan data, sebagai berikut:

1. Pengamatan (Observation)

Pengamatan langsung terhadap objek yang diteliti di lapangan pada saat melakukan Praktik Kerja Lapangan. Pengamatan langsung ke kantor tersebut untuk melihat proses kegiatannya seperti pemesanan barang, penerimaan barang yang telah dipesan oleh pihak kantor sampai pelaporan pengeluaran kas belanja bulanan. Sehingga mendapatkan informasi yang diinginkan untuk menganalisa proses pencatatan pengeluaran kas belanja bulanan yang dilakukan. Pengamatan langsung dilakukan di Ruangan Administrasi Sekretariatan Daerah Kabupaten Kubu Raya.

2. Wawancara (interview)

Penulis melakukan suatu metode tanya jawab mengenai kegiatan yang berhubungan dengan kantor khususnya kegiatan belanja bulanan dengan bagian bendahara yaitu bapak Fitriadi di Kantor Sekretariat Daerah Pemerintah Kabupaten Kubu Raya. Yang dihasilkan dari wawancara adalah kami menerima data untuk di analisa yang berupa surat pemesanan, surat pengajuan harga, dan kwitansi menerima barang.

3. Studi Pustaka

Selain observasi dan Wawancara, penulis juga melakukan tinjauan pustaka untuk melengkapi data-data yang diperlukan.

\subsection{Metode Pengembangan Software}

Menurut Rosa \& Shallahuddin, Model SDLC air terjun (waterfall) sering juga disebut model sekuensial linier (sequentian linear) atau alur hidup klasik (classic life cycle). Model air terjun menyediakan pendekatan alur hidup perangkat lunak secara sekuensial atau terutut dimulai dari analisis, desain, pengodean, pengujian, dan tahap pendukung (support) [4].

Berikut adalah gambar model waterfall sebagai metode pengembangan software.

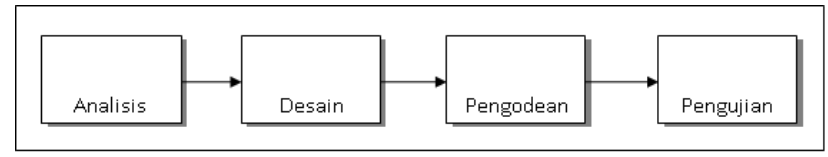

Sumber : (Rosa \& Shalahuddin, 2016)

\section{Gambar 1. Model Waterfall}

Tahap-tahap Waterfall model sebagai berikut:

1. Analisis Kebutuhan Perangkat Lunak

Proses pengumpulan kebutuhan dilakukan secara insentif untuk mendeskripsikan kebutuhan perangkat lunak agar dapat dipahami perangkat lunak seperti apa yang dibutuhkan user. Spesifikasi kebutuhan perangkat lunak pada tahap ini perlu untuk didokumentasikan. Penulis melakukan pengumpulan data dengan memperoleh informasi dari riset kemudian data tersebut dianalisis sehingga didapatkan datadata kebutuhan software yang akan dikembangkan.

2. Desain

Pada proses desain ini, penulisa merancang kebutuhan sistem dengan mendesain basis data menggunakan Entity Relationship Diagram (ERD) dan Logical Record Structure (LRS) beserta komponen-komponennya seperti entitas, atribut dan relasi dan Unified Modeling Language (UML) sebagai bahasa pemodelan untuk pembangunan perangkat lunak yang terdiri dari Use Case Diagram, Activity Diagram, class diagram, deployment diagram, dan sequence diagram.

3. Pembuatan Kode Program (Code Generation)

Pada tahapan ini, penulis kode program untuk menghasilkan website pengeluaran kas. Menggunakan bahasa pemograman Hypertext Preprocessor (PHP) untuk pengekodeannya, HyeprText Markup 
Languange (HTML). Untuk bahasa pemogramannya dengan menggunakan Sublime Text sebagai bahasa media editor dan Mysql sebagai database menggunakan (DBMS) Phpmyadmin.

4. Pengujian (Testing)

Pengujian fokus pada perangkat lunak secara dari segi lojik dan fungsional dan memastikan bahwa semua bagian sudah diuji. Hal ini dilakukan untuk meminimalisir kesalahan (error) dan memastikan keluaran yang dihasilkan sesuai dengan yang diinginkan. Dimana tahap ini penulis melakukan pengujian menggunakan blackbox testing. Blackbox testing adalah pengujian yang dilakukan dengan mengamati hasil eksekusi melalui data uji dan memeriksa fungsional dari perangkat lunak.

5. Pendukung dan pemeliharaan

Tidak menutup kemungkinan sebuah perangkat lunak mengalami perubahan ketika sudah dikirim ke user. Perubahan bisa terjadi karena adanya kesalahan yang muncul dan tidak terdeteksi saat pengujian atau perangkat lunak harus beradaptasi dengan lingkungan baru. Tahap pendukung atau pemeliharaan dapat mengulangi proses pengembangan mulai dari analisi spesifikasi untuk perubahan perangkat lunak yang sudah ada, tapi tidak untuk membuat perangkat lunak baru. Pendukung dan pemeliharaan dalam perangkat lunak dengan melakukan perbaikan kesalahan yang terjadi pada program.

\section{HASIL}

\subsection{Proses Bisnis Sistem Berjalan}

Pada bagian ini penulis akan menguraikan tentang proses sistem berjalan mengenai pengelolaan data pengeluran kas pada bagian Aministrasi Sekretariatan Kabupaten Kubu Raya, bertujuan untuk mengetahui lebih jelas bagaimana kerja dari suatu sistem dan mengetahui masalah yang dihadapi. Adapun tahapan dari proses sistem berjalan yang diterapkan oleh bagian Aministrasi Sekretariatan Kabupaten Kubu Raya, diuraikan sebagai berikut:

1. Pencatatan Pengeluaran kas

Staf Sekeretariatan Administrasi menerima data pengeluaran kas dari masing-masing bagian. Sebelum mendata pengeluaran pihak Staf akan memeriksa kelengkapan data-data untuk memastikan bahwa datadata benar adanya dan di tanda tangani oleh Kasubbag masing-masing perbagian. Apabila data sudah benar maka data pengeluaran kas tidak akan di kembalikan ke bagian dan data pengeluaran kas yang di terima selanjutnya akan di catat di Excel untuk dijadikan bahan pembuatan laporan. Tetapi apabila datadata tidak lengkap maka pihak Kasubbag administrasi akan mengembalikan data tersebut ke bagian.

2. Pengelolaan Laporan

Pada akhir bulan, Staf Admnistrasi akan mengumpulkan data pengeluaran kas untuk di jadikan sebagai laporan pengeluaran kas untuk diserahkan kepada Kasubbag Administrasi. Kasubbag Administrasi memeriksa laporan-laporan tersebut, apabila disetujui, maka Kasubbag Administrasi akan menandatangani atau memberi pengesahan di laporan tersebut kemudian disimpan ke dalam arsip bulanan, apabila tidak disetujui (terdapat kesalahan dalam pembuatan laporan), maka Kasubbag perbagian harus membuat laporan kembali.

\subsection{Activity Diagram}

\subsubsection{Activity Diagram Sistem Berjalan}

Setelah melakukan riset atau penelitian pada bagian administarsi dapat diketahui gambaran dan proses pendataan pengeluaran kas. Proses yang sudah diketahui ini, kemudian dimodelkan ke dalam bentuk Activity Diagram . Adapun hasil pemodelan untuk setiap prosedur atau tahapan pada proses sistem menjadi Activity Diagram dapat dilihat pada gambar berikut ini.

1. Activity Diagram pencatatan Pengeluaran Kas

Proses yang telah diuraikan untuk pencatatan pengeluaran kas pada sub-bab sebelumnya akan dimodelkan ke dalam bentuk Activity Diagram. 
Sumber : Hasil Perancangan (2020)

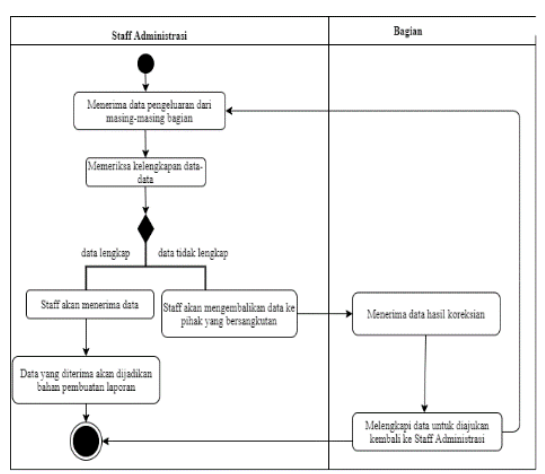

\section{Gambar 2. Activity Diagram Pencatatan Pengeluaran Kas}

Staf administrasi menerima data pengeluaran kas dari masing-masing bagian. Sebelum mendata pengeluaran pihak Staf Administrasi akan memeriksa kelengkapan data-data untuk memastikan bahwa data-data benar adanya dan di tanda tangani oleh Kasubbag masing-masing perbagian. Apabila data sudah benar maka data pengeluaran kas tidak akan di kembalikan ke bagian dan Data pengeluaran kas yang di terima selanjutnya akan di catat di Excel untuk dijadikan bahan pembuatan laporan. Tetapi apabila data-data tidak lengkap maka pihak Kasubbag administrasi akan mengembalikan data tersebut ke bagian.

2. Activity Diagram Pengelolaan Laporan

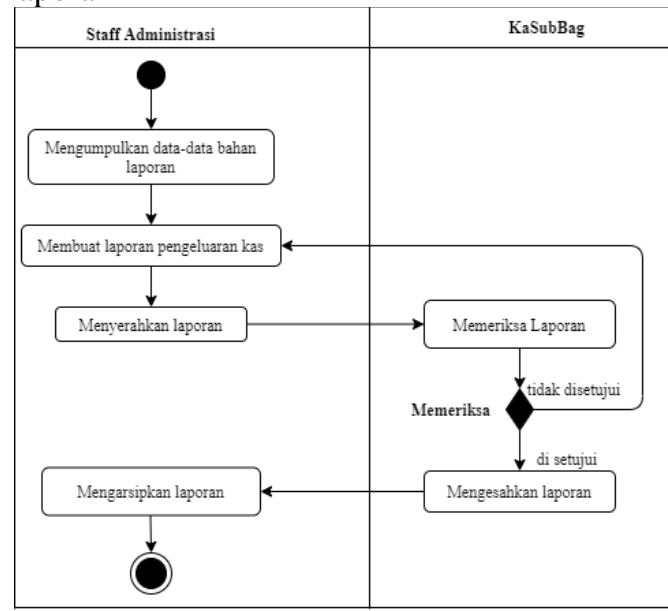

Sumber : Hasil Perancangan (2020)

Gambar 3. Activity Diagram Pengelolaan Laporan

Pada akhir bulan, Staf administrasi mengumpulkan data pengeluaran kas untuk di jadikan sebagai laporan pengeluaran kas untuk diserahkan kepada Kasubbag. Kasubbag memeriksa laporan-laporan tersebut, apabila disetujui, maka Bendahara akan menandatangani atau memberi pengesahan di laporan tersebut kemudian disimpan ke dalam arsip bulanan, apabila tidak disetujui (terdapat kesalahan dalam pembuatan laporan), maka Kasubbag harus membuat laporan kembali.

\subsubsection{Analisa Kebutuhan Perangkat Lunak}

Perangkat lunak yang baik dan sesuai dengan kebutuhan pengguna dapat tergantung analisa kebutuhannya. Analisa sistem ini sangat dibutuhkan dalam mengidentifikasi data dan proses yang dibutuhkan sistem. Sistem yang digunakan harus sesuai dengan kebutuhan dari Sekretariatan Daerah Kabupaten Kubu Raya, maka terdapat beberapa kebutuhan dalam pengelolahan data Pengguna, Pengeluaran kas, Program, Rincian Kegiatan, dan Bagian. Program ini dapat digunakan oleh Staf Sekretariatan Administrasi dan Kepala Sub Bagian (Kasubbag) Sekretariatan dengan tujuan untuk membantu dan memudahkan transaksi pengeluaran dana kas kecil agar lebih efesien dan efektif dalam penyimpanan data maupun transaksi. 


\subsubsection{Tahapan Analisis}

Berdasarkan proses sistem berjalan pada Bagian Administrasi Sekretariatan Kabupaten Kubu Raya, maka selanjutnya akan menjelaskan tentang analisis kebutuhan. Berikut adalah spesifikasi kebutuhan (System Requirement) dari sistem.

1. Kebutuhan Akses Staf Sekretariat Administrasi

A.1 Pengguna Login

A.2. Mengelolah data Pengeluaran Kas

A.2.1.Input Data Pengeluaran Las

A.3. Mengelolah Data Bagian

A.3.1.Input Data Bagian

A.4. Mengelolah Data Program

A.4.1.Input Program Kerja

A.4.2.Input Rincian Kegiatan

A.5. Pengguna Logout

2. Kebutuhan Akses Kepala Sub Bagian Administrasi

B.1. Pengguna Login

B.2. Mengelolah Data Pengeluaran Kas

B.2.1.Input Data Pengeluaran Las

B.3. Mengelolah Data Bagian

B.3.1.Input Data Bagian

B.4. Mengelolah Data Program

B.4.1.Input Program Kerja

B.4.2.Input Rincian Kegiatan

B.5. Mengelolah Data Pengguna

B.5.1.Input Data Pengguna

B.6. Melihat Laporan Pengeluaran Kas

B.6.1.Melihat dan Mencetak Laporan Pengeluaran Kas

B.7. Pengguna Logout

\subsubsection{Use Case Diagram}

Use Case Diagram merupakan pemodelan untuk menggambarkan kelakuan sistem yang akan dibuat, menggambarkan proses bisnis dan juga urutan aktivitas yang ada dalam sebuah proses dan mendiskripsikan sebuah materaksi antara satu atau lebih actor dengan sistem yang akan dibuat. Use Case Diagram yang digunakan untuk mengetahui fungsi apa saja yang ada didalam sistem dan siapa saja yang menggunakan fungsi-fungsi tersebut.

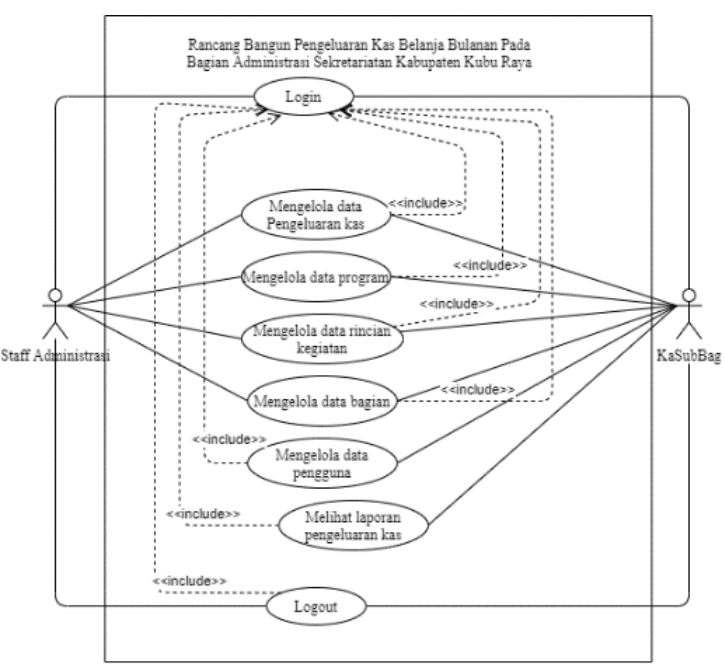

Sumber : Hasil Perancangan (2020)

Gambar 1. Use Case Diagram Pengeluaran Kas Belanja Bulanan 
Berdasarkan gambar 4 di atas, sistem yang dirancang ini terdiri dari dua (2) level akses, yaitu Staf Sekretariatan Administras dan Kepala Sub Bagian Administrasi ( Kasubbag Admin ). Staf Administrasi dapat mengelola data master yang terdiri: mengelolah data pengeluaran kas, mengelolah data bagian, mengelolah data program dan mengelolah data rincian kegiatan. Kasubbag dapat mengelola data master: yaitu data Pengguna, mengelolah data pengeluaran kas, mengelola data program, mengelolah data rincian kegiatan, mengelolah data bagian dan melihat laporan pengeluaran kas.

\subsubsection{Desain}

\subsubsection{Entity Relationship Diagram (ERD)}

Entity Relationship Diagram (ERD) digunakan sebagai teknik pemodelan rancangan basis data untuk menjelaskan hubungan antar entitas di dalam basis data berdasarkan objek-objek yang mempunyai hubungan antar relasi. Berikut ini adalah bentuk dari Entity Relationship Diagram (ERD) untuk rancangan basis data dari Pengeluaran kas belanja bulanan pada bagian administrasi Sekretariatan Daerah Kabupaten Kubu Raya.

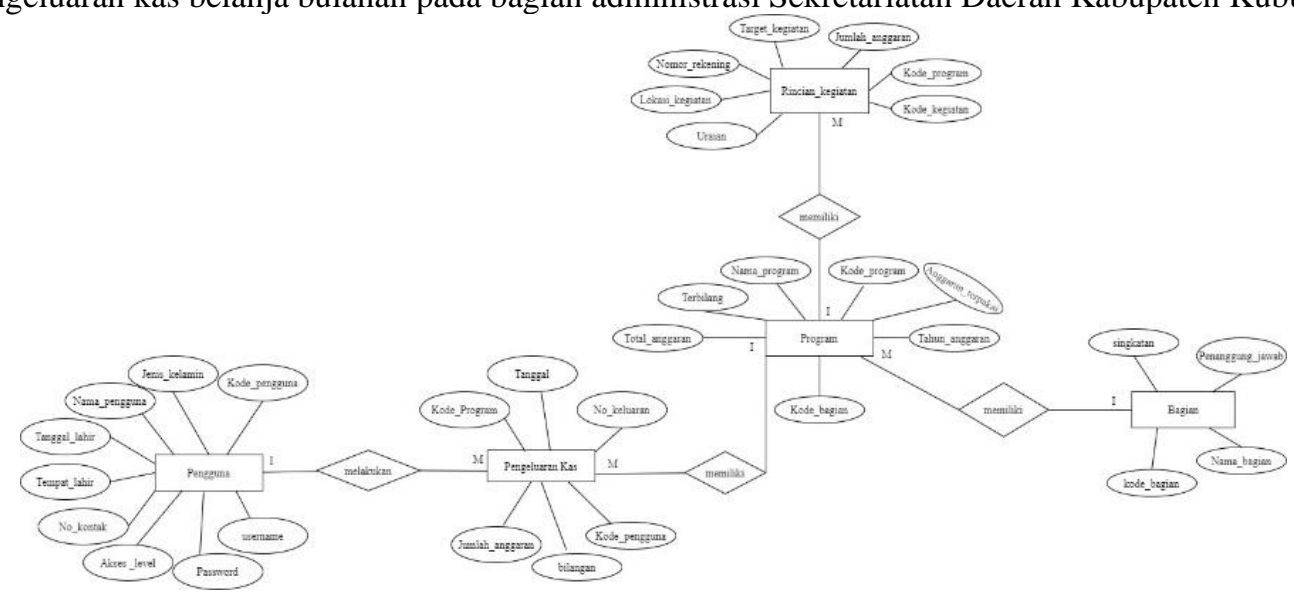

Sumber : Hasil Perancangan (2020)

Gambar 5 Entity Relationship Diagram (ERD)

Pada gambar 5 di atas dapat dijelaskan bahwa Pengguna memiliki atribut : id_pengguna, jenis_kelamin, nama_pengguna, tanggal_lahir, tempat_lahir, no_kontak, akses_level, password, dan username yang berelasi ke tabel pengeluaran kas yang mempunyai atribut : kode_program, tanggal, no_keluaran, jumlah_anggaran, bilangan, dan kode_pengguna yang berelasi ke tabel program yang mempunyai atribut : kode_program, tahun_anggaran, ,anggaran_terpakai, terbilang, nama_program, kode_bagian, dan total anggaran yang berelasi ke table rincian kegiatan yang mempunyai atribut : kode_kegiatan, kode_program,jumlah_anggaran, target_kegaitan, nomor_rekening, lokasi_kegiatan, dan uraian yang berelasi ke table bagian yang mempunyai atribut : kode_bagian, nama_bagian, singkatan, dan penanggunag jawab.

\subsubsection{Logical Record Structure (LRS)}

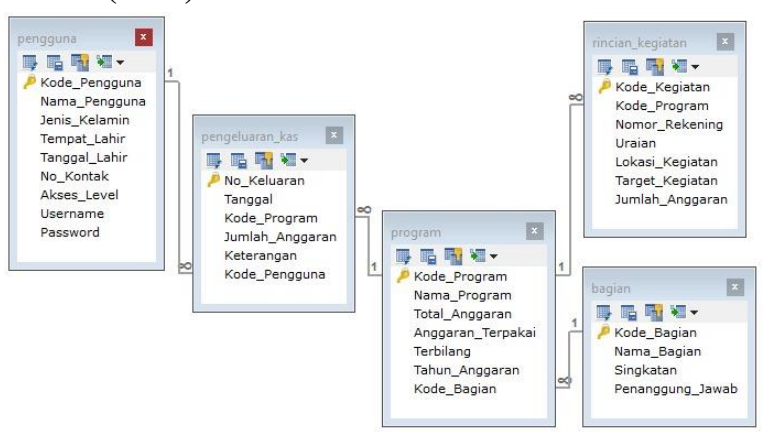

Sumber : Hasil Perancangan (2020)

Gambar 6. Logical Record Structure (LRS)

Pada gambar 6 di atas dapat dijelaskan bahwa tabel pengguna (kode_pengguna) berelasi ke tabel pengeluaran (no_keluaran) yaitu one to many. Tabel pengeluaran (no_keluaran) berelasi ke tabel program (kode_program) many to one. Tabel program (kode_program) berelasi ke tabel rincian kegiatan (kode_kegiatan) one to many dan Tabel program (kode_program) berelasi ke tabel bagian (kode_bagian) many to one. 


\subsubsection{User Interface}

\subsubsection{User Interface Login}

Pengguna memiliki hak yang sama yaitu dapat melihat halaman login. Berikut ini adalah halaman login aplikasi berbasis website:

Sumber : Hasil Perancangan (2020)

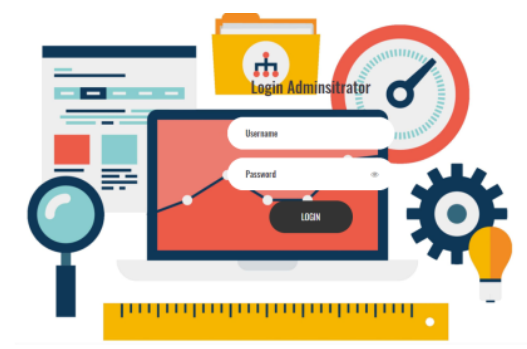

\section{Gambar 7. User Interface login}

Gambar 7 berikut adalah user interface login rancangan sistem Pengeluaran kas pada Bagian Administrasi dimana login disini terdapat name dan password yang harus di isi, setelah diisi dan masuk berhasil maka sistem akan menampilkan menu utama.

\subsubsection{User Interface Beranda}

Pengguna memiliki hak yang sama yaitu dapat melihat halaman login. Berikut ini adalah halaman beranda aplikasi berbasis website :

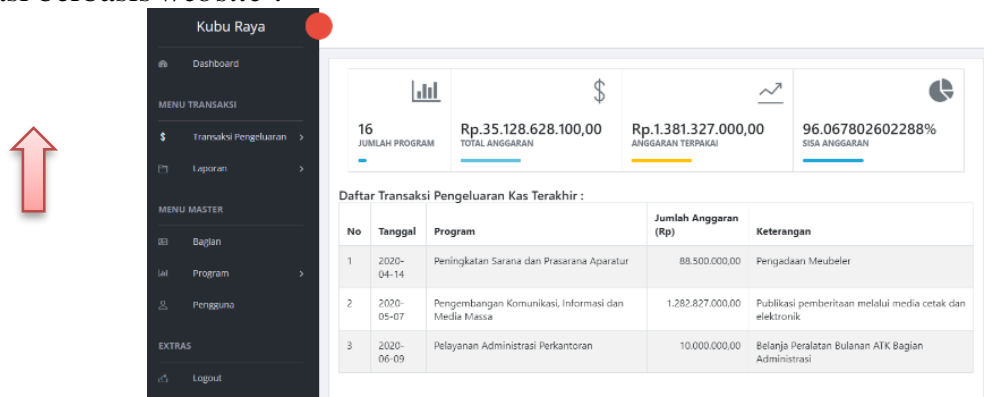

Sumber : Hasil Perancangan (2020)

\section{Gambar 8. User Interface Beranda}

Gambar 8. berikut adalah user interface menu utama rancangan sistem Pengeluaran kas pada Bagian Administrasi dimana menu beranda disini terdapat menu Transaksi data pengeluaran dan menu master serta di menu beranda Staf dapat melihat jumlah program, total anggaran pertahun, anggaran terpakai, sisa anggaran dan daftar transaksi pengeluaran kas terakhir. Pada menu utama ini terdapat tombol keluar jika ingin keluar dari sistem.

\subsubsection{User Interface Transaksi Pengeluaran Kas}

Pengguna memiliki hak yang sama yaitu dapat melihat halaman transaksi pengeluaran kas. Berikut ini adalah halaman transaksi pengeluaran kas aplikasi berbasis website :

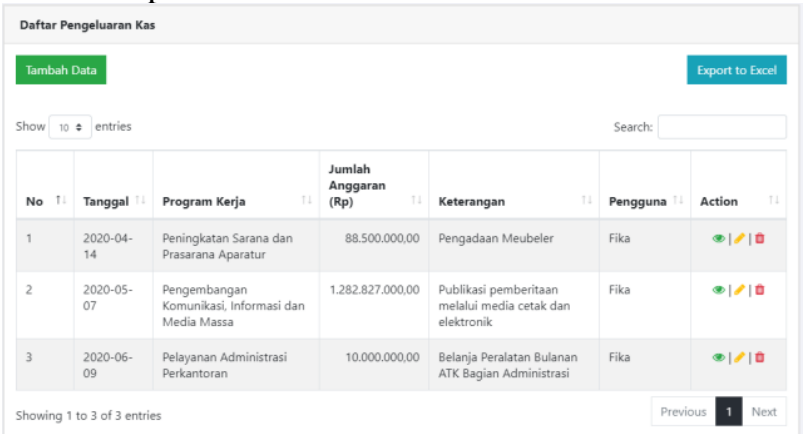

Sumber : Hasil Perancangan (2020)

Gambar 9. User Interface Transaksi Keuangan

Gambar 9. berikut adalah user interface menu Transaksi Pengeluaran Kas rancangan sistem pengeluaran kas pada bagian administrasi dimana menu pengeluaran kas disini terdapat pencarian daftar pengeluaran kas, 
daftar pengeluaran kas, edit, tambah, dan hapus. Untuk mencetak transaksi pengeluaran kas staf bisa menekan Export to Excel.

\subsubsection{User Interfase Pengelolaan Data Pengeluaran Kas}

Pengguna memiliki hak yang sama yaitu dapat melihat halaman pengelolaan data pengeluaran kas. Berikut ini adalah halaman pengelolaan data pengeluaran kas aplikasi berbasis website :
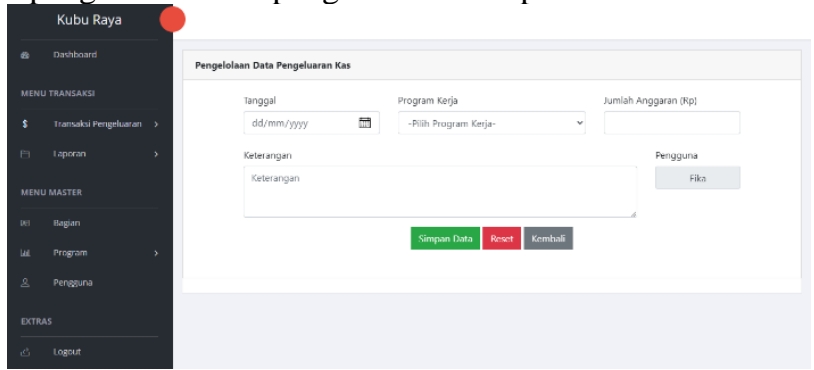

Sumber : Hasil Perancangan (2020)

\section{Gambar 10. User Interface Menu Pengelolaan Data Pengeluaran Kas}

Gambar 10 di atas adalah user interface menu Pengelolaan data pengeluaran kas rancangan sistem Pengeluaran kas pada Bagian Administrasi dimana Staf Administrasi harus mengisi Tanggal pengeluaran, Program Kerja, Jumlah Anggaran dan Keterangan program kerja yang berfungsi untuk menambahkan data transaksi pengeluaran kas.

\section{KESIMPULAN}

Berdasarkan hasil pengamatan dan pengumpulan data pada Bagian Administrasi Sekretariatan Daerah Kabupaten Kubu Raya. Maka penulis memberikan kesimpulan sebagai berikut :

1. Sebelum adanya aplikasi rancang bangun pengeluaran kas belanja bulanan, Sistem pencatatan perencanan Belanja Bulanan yang digunakan oleh kantor Sekretariatan Daerah Kabupaten Kubu Raya masih manual yaitu masih mencacat menggunakan Word dan Excel dalam proses pencatatan belanja bulanan yang digunakan hanya data-data laporan pengeluaran kas bulanan. Sehingga sering terjadinya kesalahan dalam pencatatan dan pembukuan, Tidak adanya tempat untuk menyimpan bukti transaksi laporan pengeluaran kas yang menyebabkan seringnya kehilangan bukti laporan transaksi tersebut sehingga penulis merancang aplikasi rancang bangun pengeluaran kas belanja bulanan pada bagian Administrasi Sekretariatan Kabupaten Kubu Raya untuk memudahkan proses pencatatan pengeluaran kas belanja bulanan.

2. Aplikasi rancang bangun pengeluaran kas ini dibangun untuk bagian Administrasi Sekretariatan Daerah Kabupaten Kubu Raya memberikan fasilitas kepada pengguna, pengguna yang terdiri dari Staf Administrasi dan Kasubbag Administrasi. Staf Administrasi dapat mengolah data transaksi pengeluaran kas, data bagian, dan data program kerja. Sedangkan Kasubbag (Kepala Sub Bagian) Administrasi dapat mengakses data transaksi pengeluaran kas, data bagian, data program kerja, data pengguna dan mengakses laporan pengeluaran kas belanja bulanan.

3. Dampak dan Manfat dari aplikasi rancang bangun pengeluaran kas ini adalah terdapatnya sistem yang terkomputerisasi sehingga dapat memanilisir terjadinya kesalahan-kesalahan dalam pencatatan dan perhitungan, maupun penyimpanan data. Dapat menghasilkan suatu informasi yang lebih efesien tepat waktu dan relefen. Data yang disimpan didalam sistem komputerisasi akan lebih terjaga, sehingga tidak sembarangan orang bisa melihat data-data yang penting mengenai data keuangan atau informasi dalam perusahaan. Sistem komputerisasi merupakan suatu sistem yang memudahkan karyawan dalam melakukan aktivitas pekerjaan tiap harinya.

4. Aplikasi pengeluaran kas yang dibangun ini diharapkan dapat membantu meningkatkan kinerja pengolahan pengeluaran kas pada Administrasi Sekretariatan Daerah Kabupaten Kubu Raya.

\section{UCAPAN TERIMA KASIH}

Penulis menyadari bahwa tanpa bimbingan dan dorongan dari semua pihak, maka jurnal ini tidak akan lancar. Oleh karena itu, pada kesempatan ini penulis ingin menyampaikan terima kasih kepada:

1. Rektor Universitas Bina Sarana Infomatika.

2. Wakil Rektor 1 Bidang Akademik Universitas Bina Sarana Informatika.

3. Dekan Fakultas Teknik dan Infomasi Universitas Bina Sarana Informatika. 
4. Ibu Lisnawaty, ST, M.Kom Selaku Ketua Program Studi Sistem Informasi Akuntansi Kampus Kota Pontianak, Fakultas Teknik dan Informasi Universitas Bina Sarana Informatika Kota Pontianak.

5. Ibu Dra. Novita Purbasari, M.Si Selaku Kepala Bagian Administrasi Sekretaria Daerah Kabupaten Kubu Raya.

6. Ibu Syarifah Tri Pahlawati selaku Kepala Sub Bagian Administrasi Sekretaria Daerah Kabupaten Kubu Raya.

7. Bapak Gabriel Edit selaku Kepala Bendahara Sekretariat Daerah Kabupaten Kubu Raya.

8. Ibu Windi Irmayani SE. M.Kom.

9. Rekan-rekan Dosen Universitas Bina Sarana Infomatika PSDKU Pontianak

Serta semua pihak yang telah membantu penulis dalam menyelesaikan jurnal ini yang tidak dapat disebutkan satu persatu.

\section{REFERENSI}

[1] Aisyah, N. (2017). Sistem Pengendalian Internal Atas Fungsi Penerimaan Kas Dan Pengeluaran Kas Pada P.T. Sarana Hachery Abadi. Jurnal Economix, 5(1), 167-175. Https://Doi.Org/10.1016/J.Neuroimage.2007.11.048

[2] Ilmiah, J., Informasi, S., Jisti, I., Kantor, D. I., Dan, A., Ruang, T., \& Pertanahan, B. (2020). Pengembangan Sistem Informasi Peralihan Hak Atas Tanah. 3(April), 46-55.

[3] Juniardi Dermawan, S. H. (2017). "Implement.” Notes And Queries, 19(159), 37. Https://Doi.Org/10.1093/Nq/S5VII.159.37-A

[4] Riadi, M. (2019). Pengertian Audit Sistem Informasi. Kajian Pustaka, 1-7. Http://Www.Kajianpustaka.Com/2014/02/Audit-Sistem-Informasi.Html

[5] Tata, R., Wilayah, R., Kubu, K., \& Tahun, R. (2016). Rencana Tata Ruang Wilayah Kabupaten Kubu Raya Tahun 2016-2036 1. 1-80. 